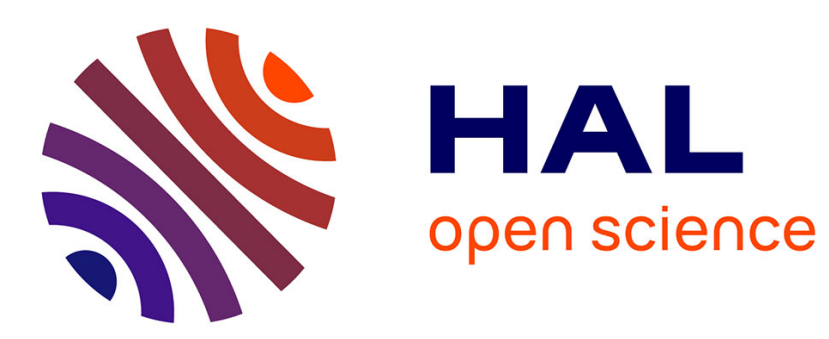

\title{
La politique antidiscriminatoire de l'Union Européenne
}

Daniel Borrillo

\section{To cite this version:}

Daniel Borrillo. La politique antidiscriminatoire de l'Union Européenne. Daniel Borrillo. Lutter contre les discriminations, La Découverte, 2003, 2-7071-4027-9. hal-01237739

\section{HAL Id: hal-01237739 \\ https://hal.science/hal-01237739}

Submitted on 3 Dec 2015

HAL is a multi-disciplinary open access archive for the deposit and dissemination of scientific research documents, whether they are published or not. The documents may come from teaching and research institutions in France or abroad, or from public or private research centers.
L'archive ouverte pluridisciplinaire HAL, est destinée au dépôt et à la diffusion de documents scientifiques de niveau recherche, publiés ou non, émanant des établissements d'enseignement et de recherche français ou étrangers, des laboratoires publics ou privés. 

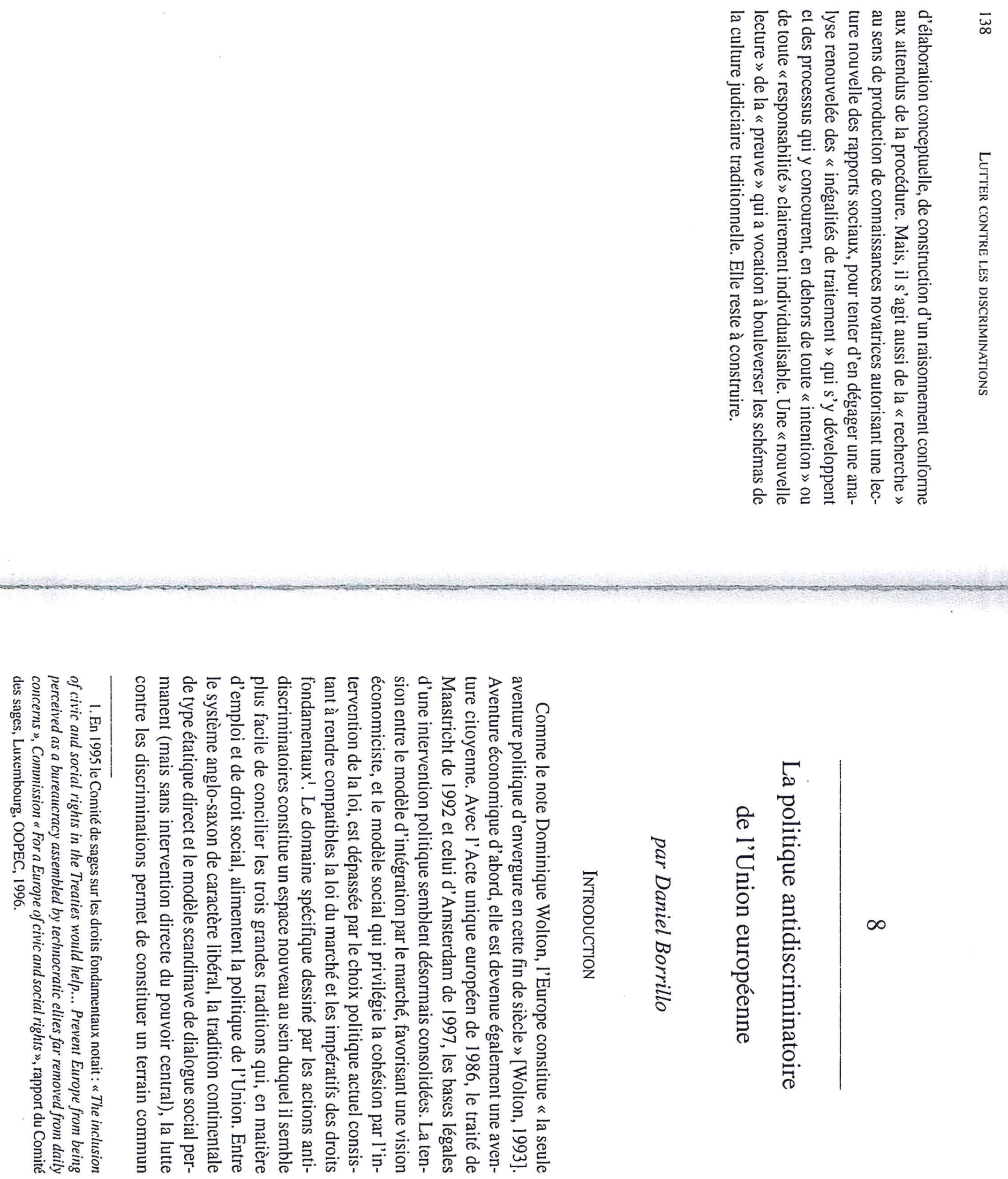


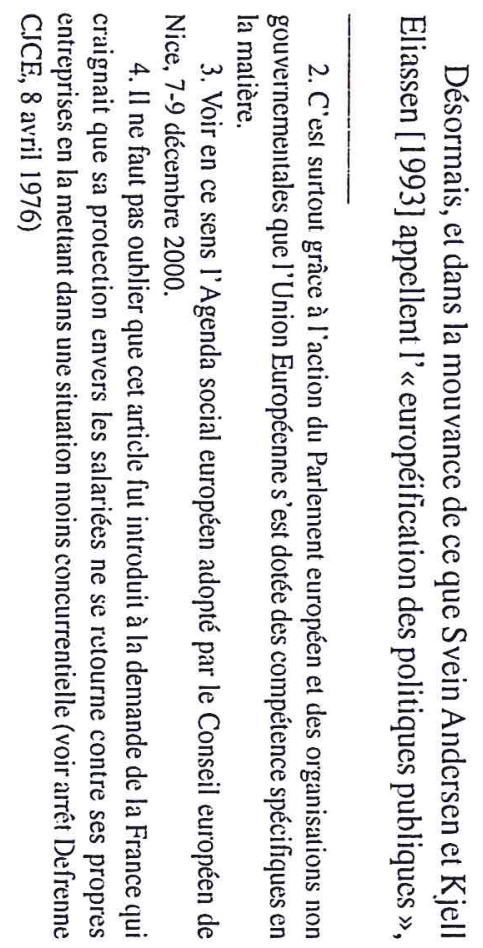

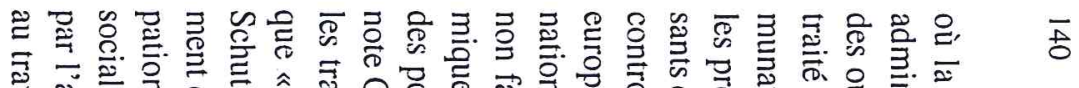

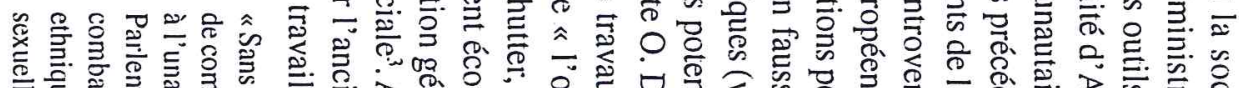

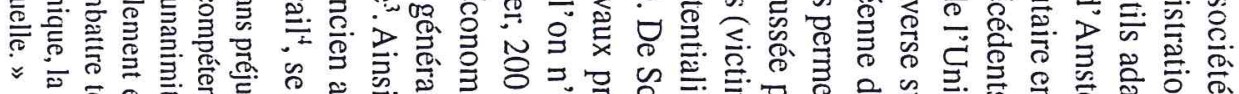

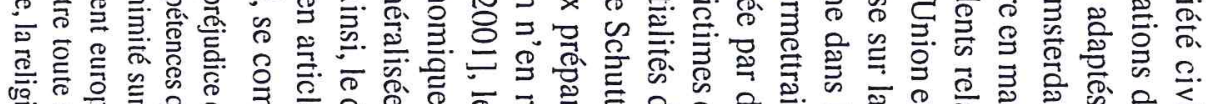

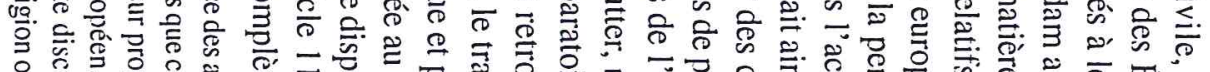

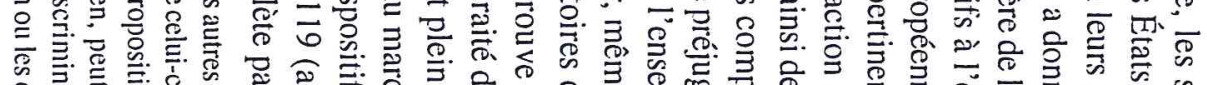

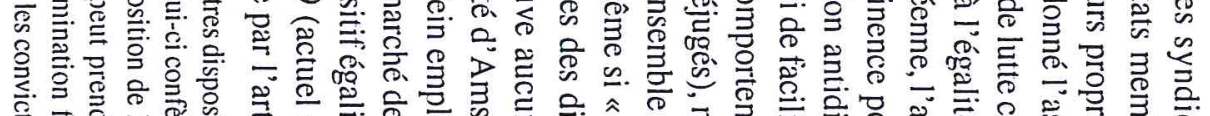

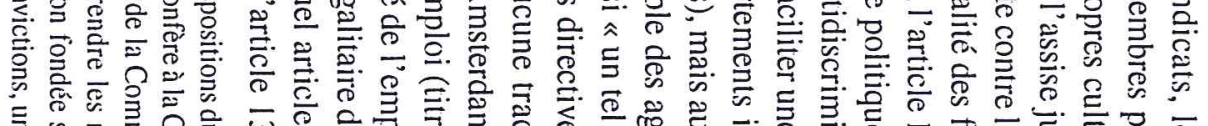

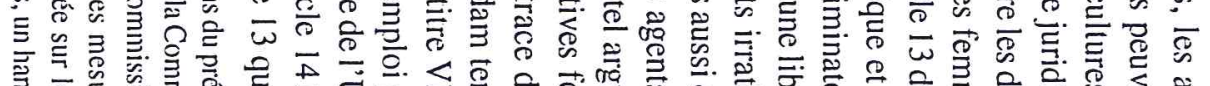

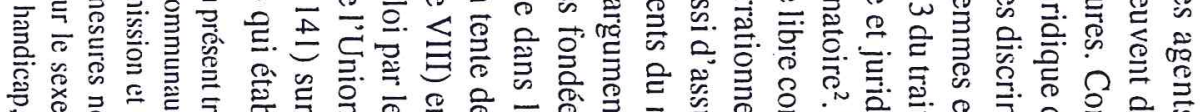

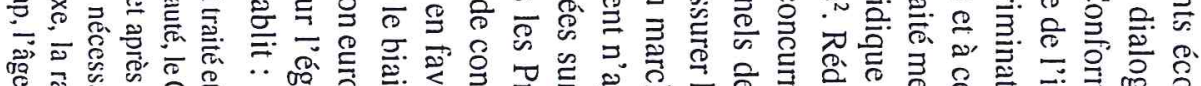

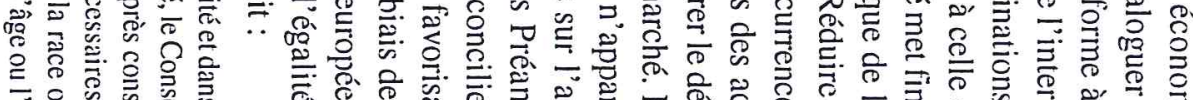

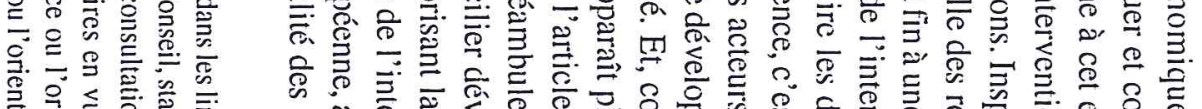

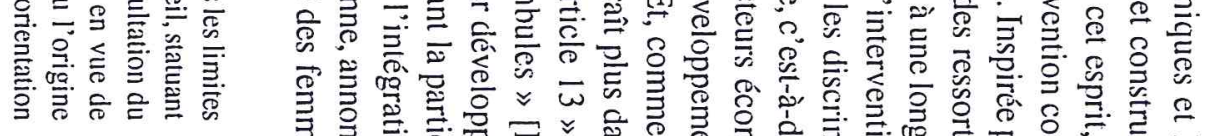

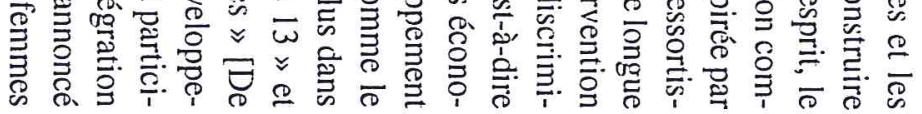

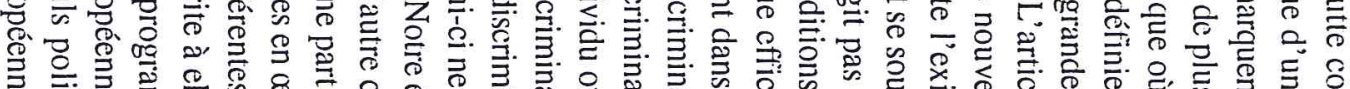

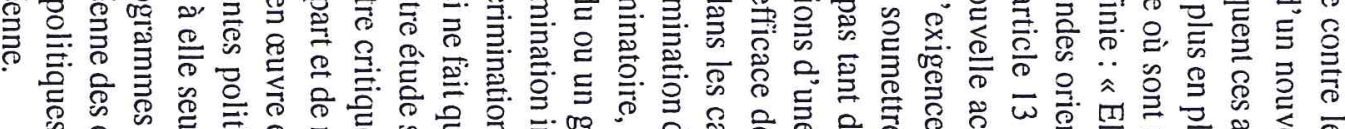

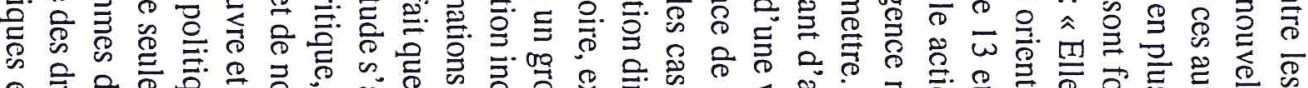

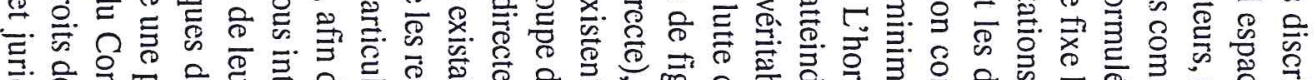

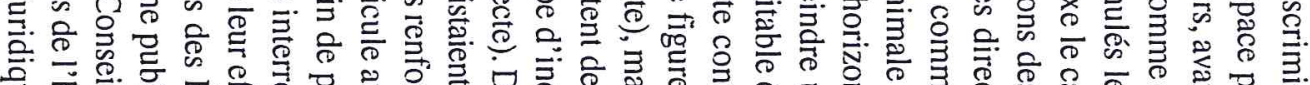

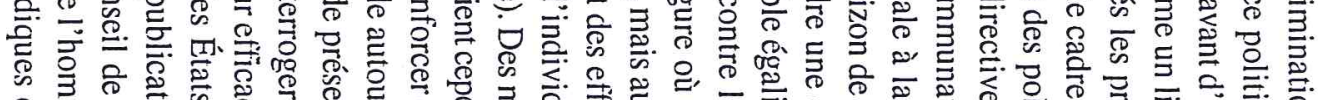

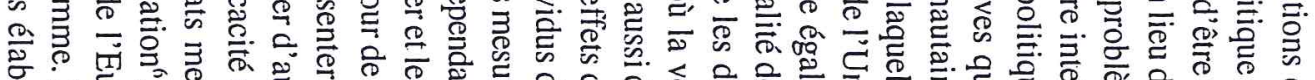

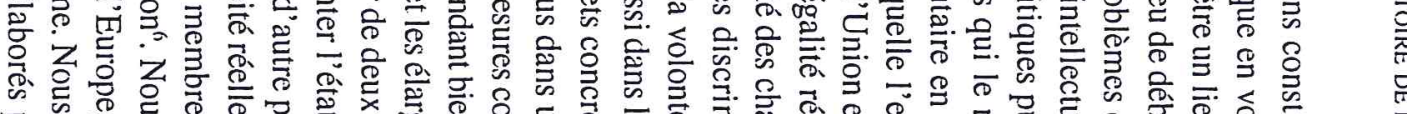

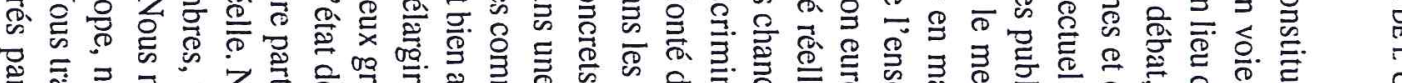

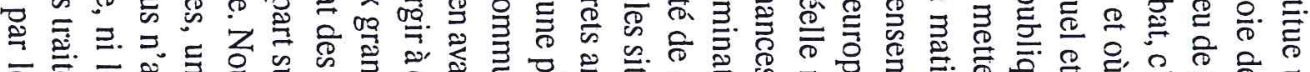

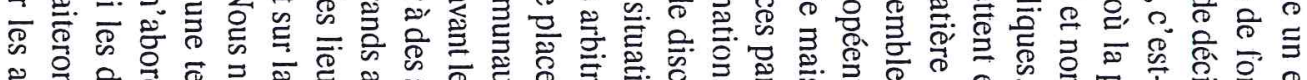

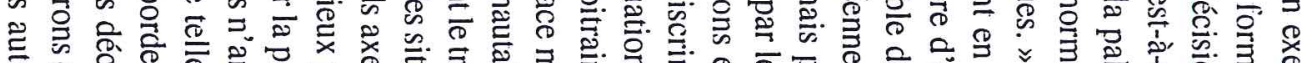

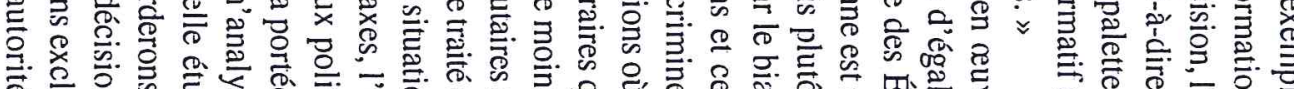

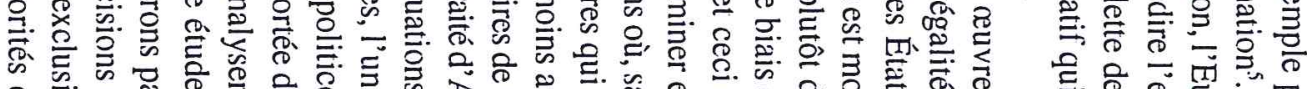

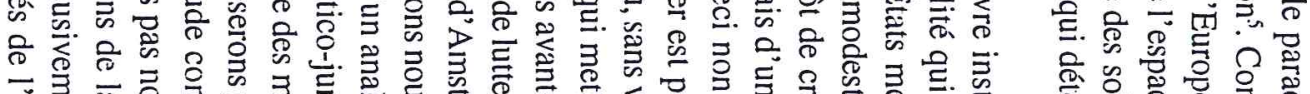

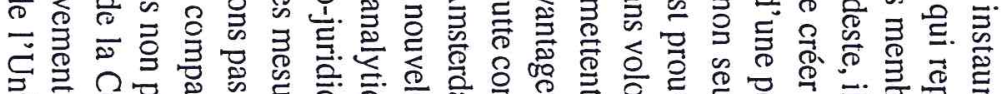

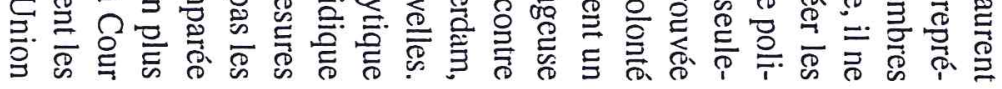

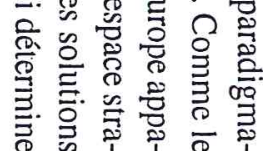




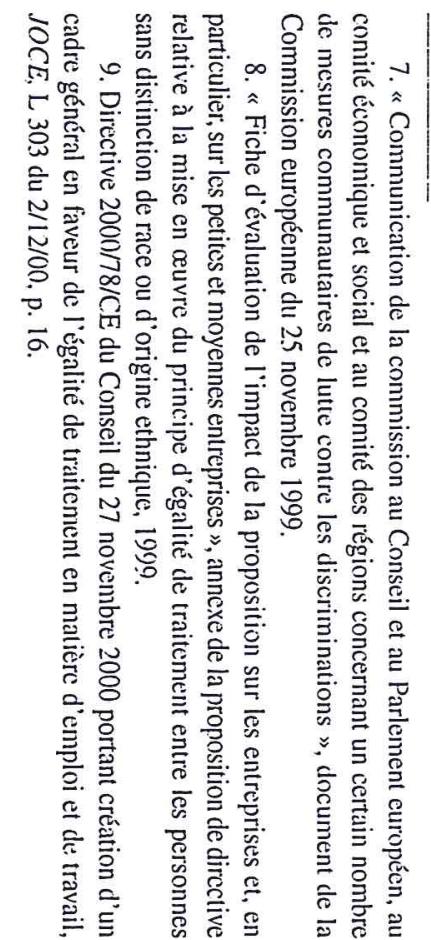

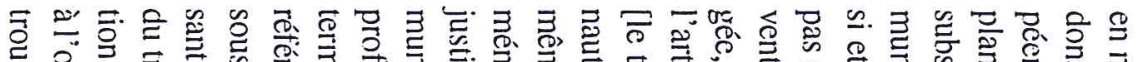

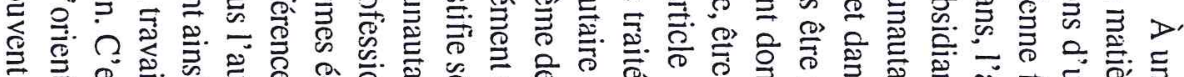

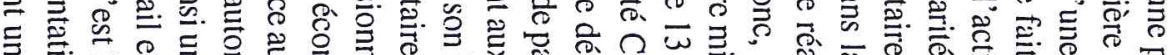

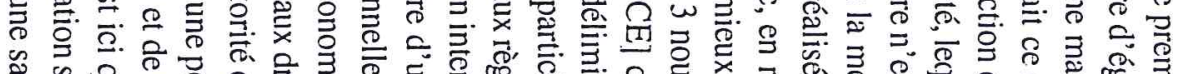

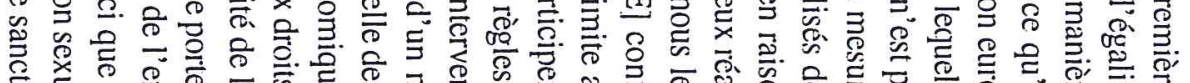

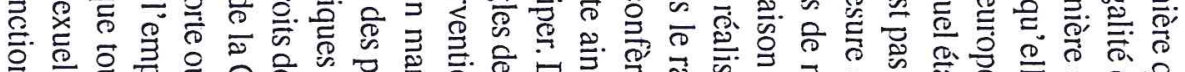

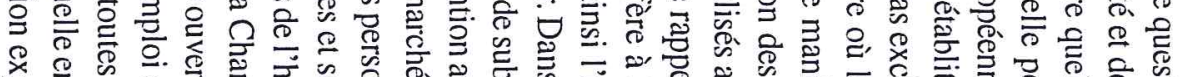

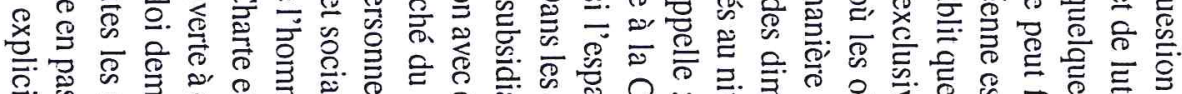

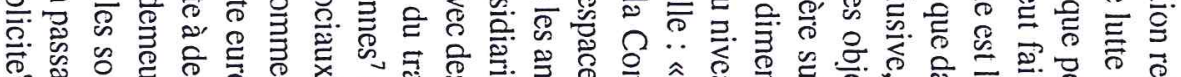

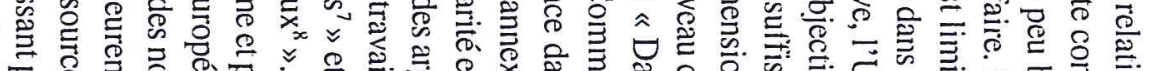

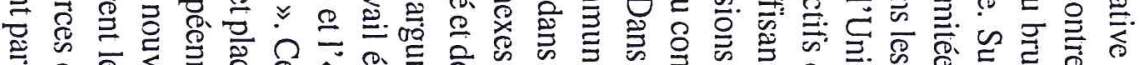

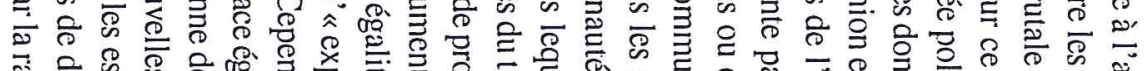

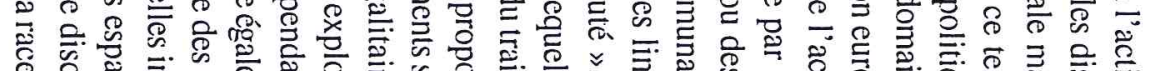

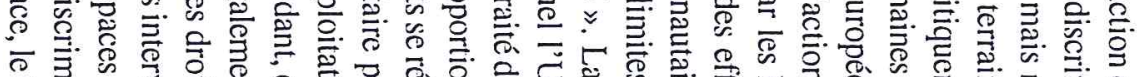

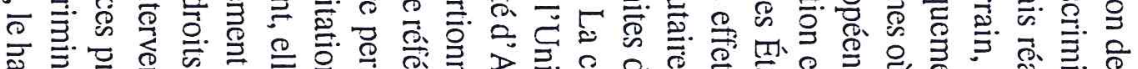

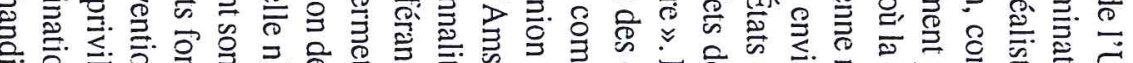

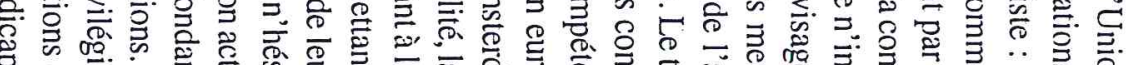

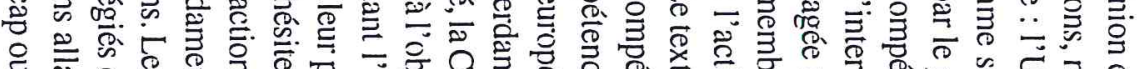

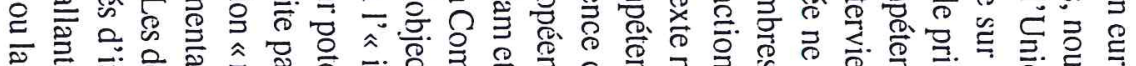

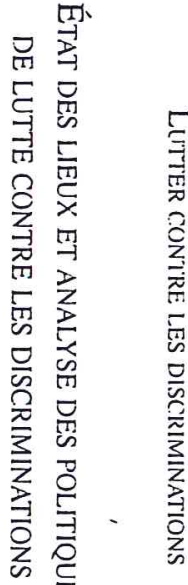

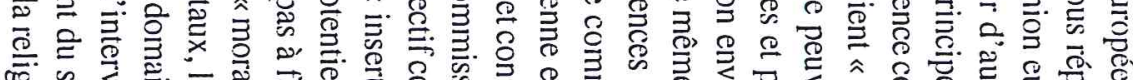

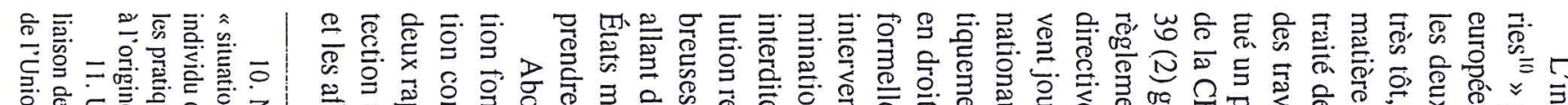

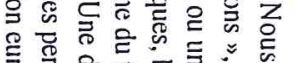

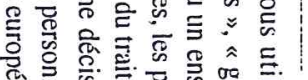

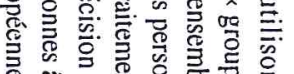

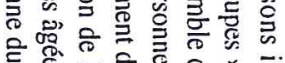

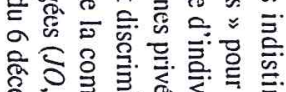

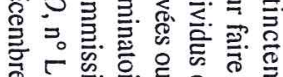

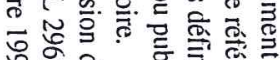

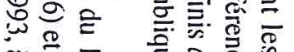

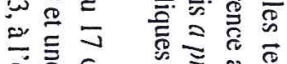

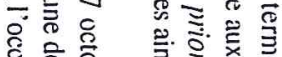

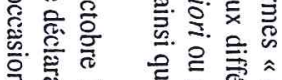
के कृ

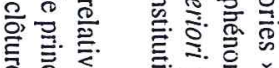

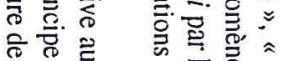
可器

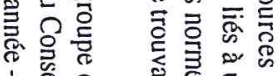

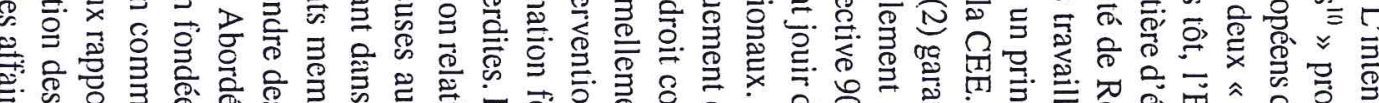

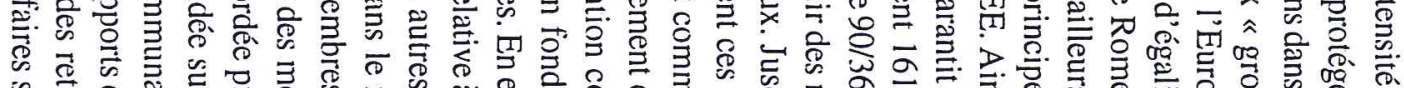

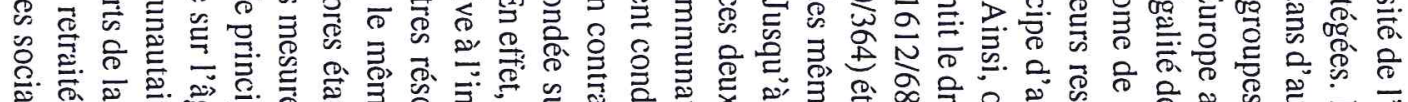

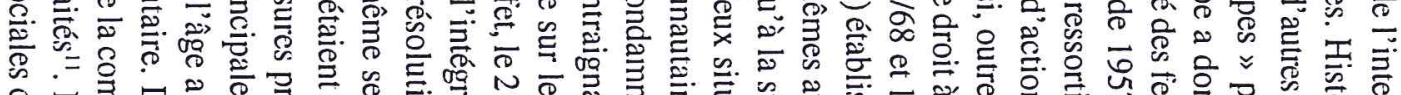

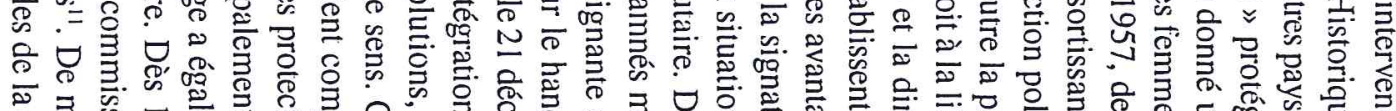

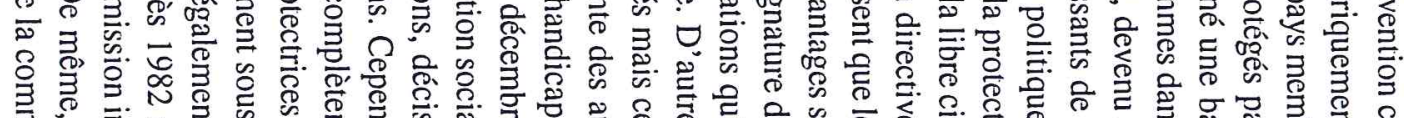

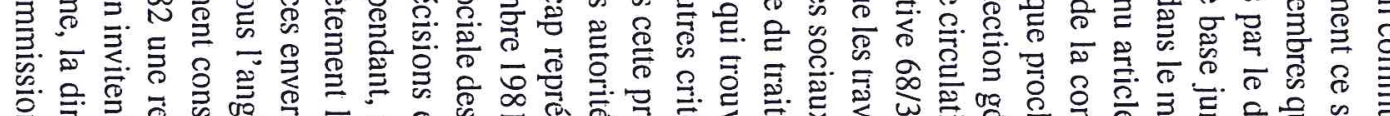

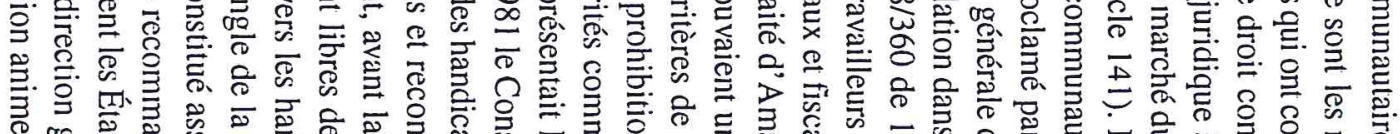

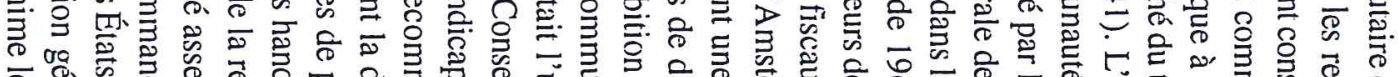

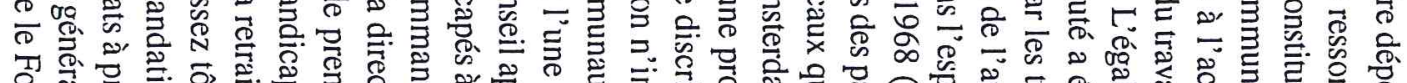

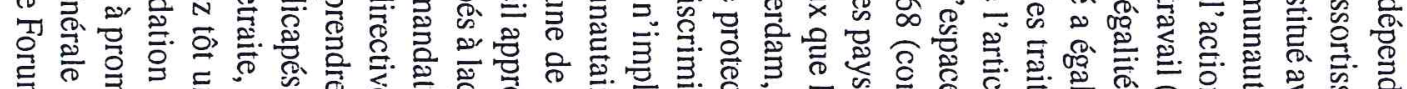

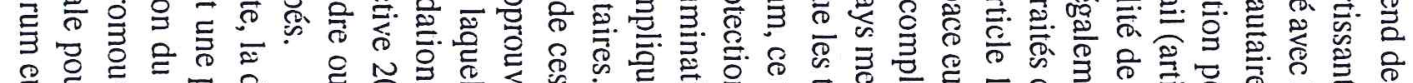

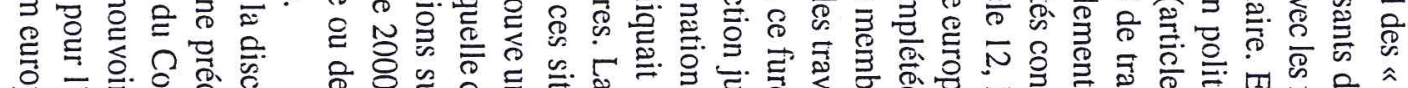

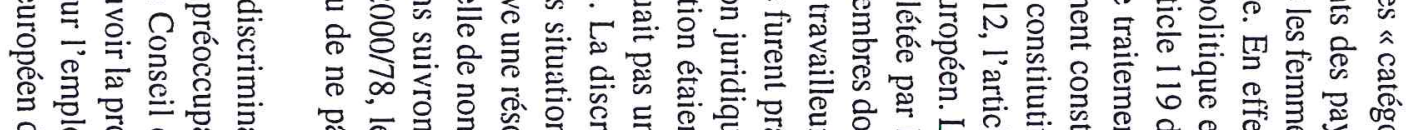




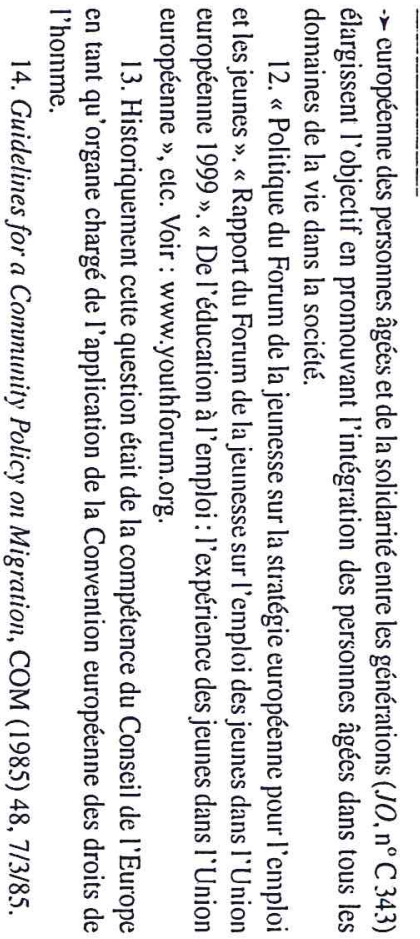

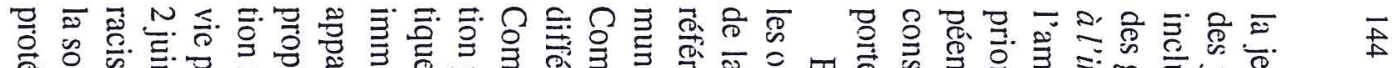

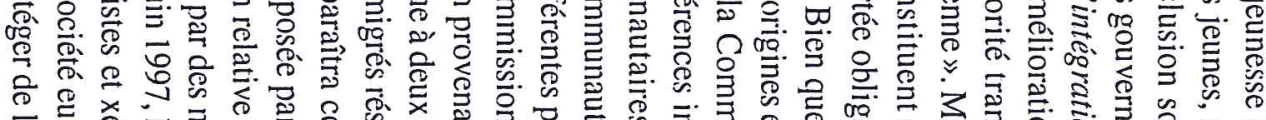

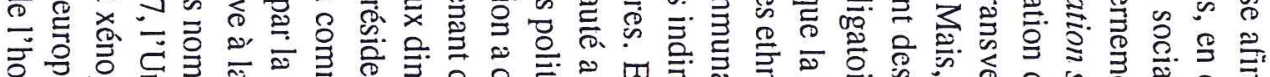

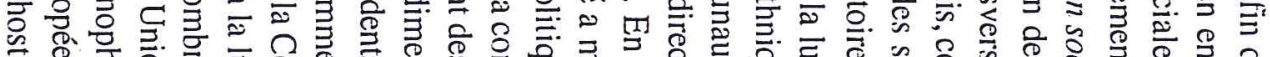

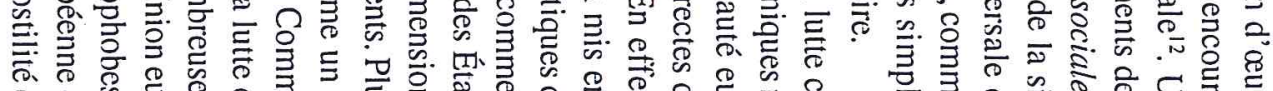

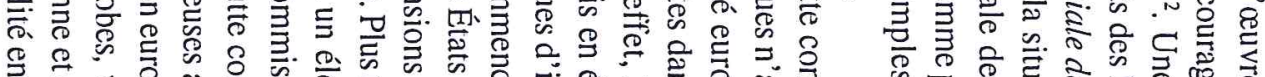

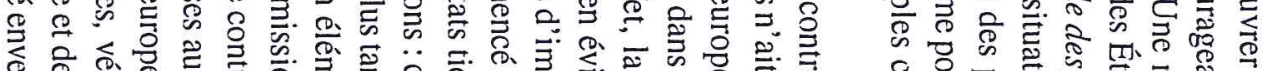

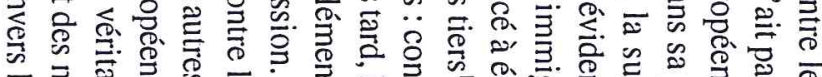

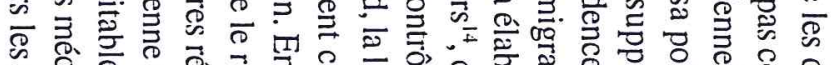

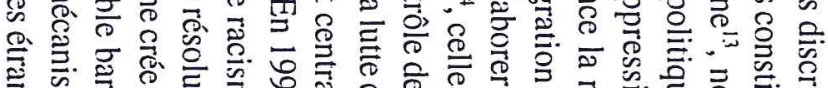

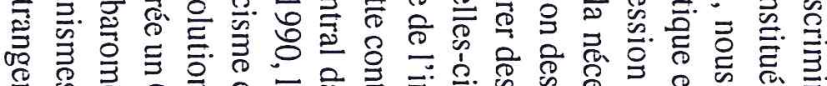

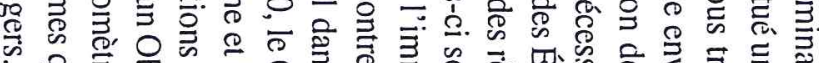

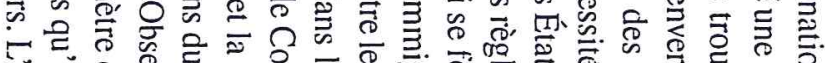

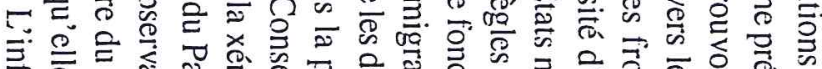

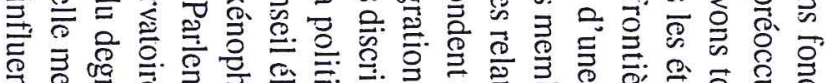

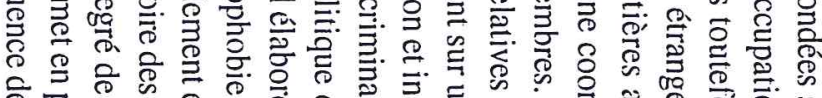

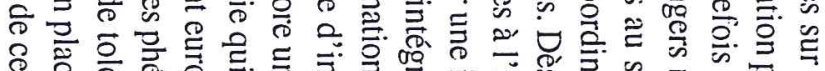

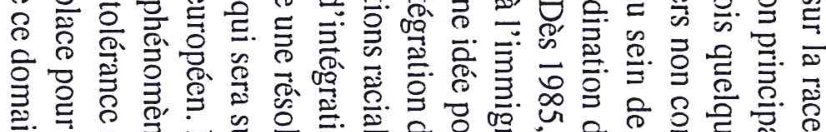

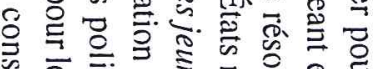

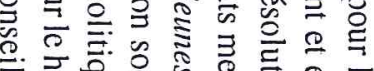
क 氠莡

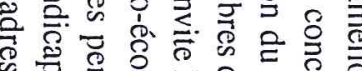
क

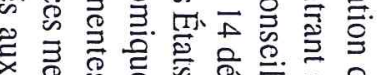

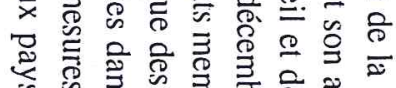
उ

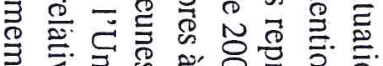

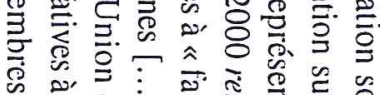

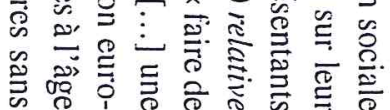

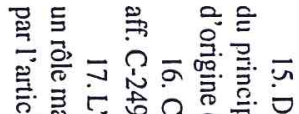

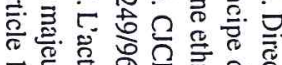

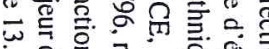

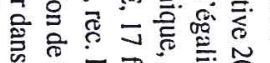

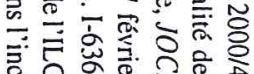

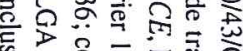

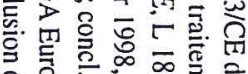

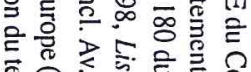

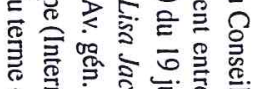

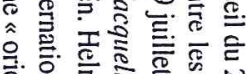

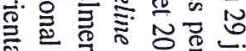
항.

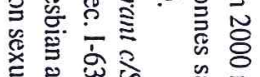

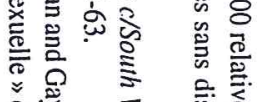

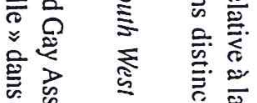

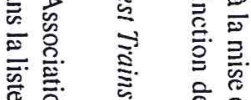

ते

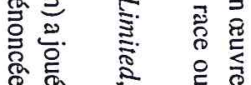

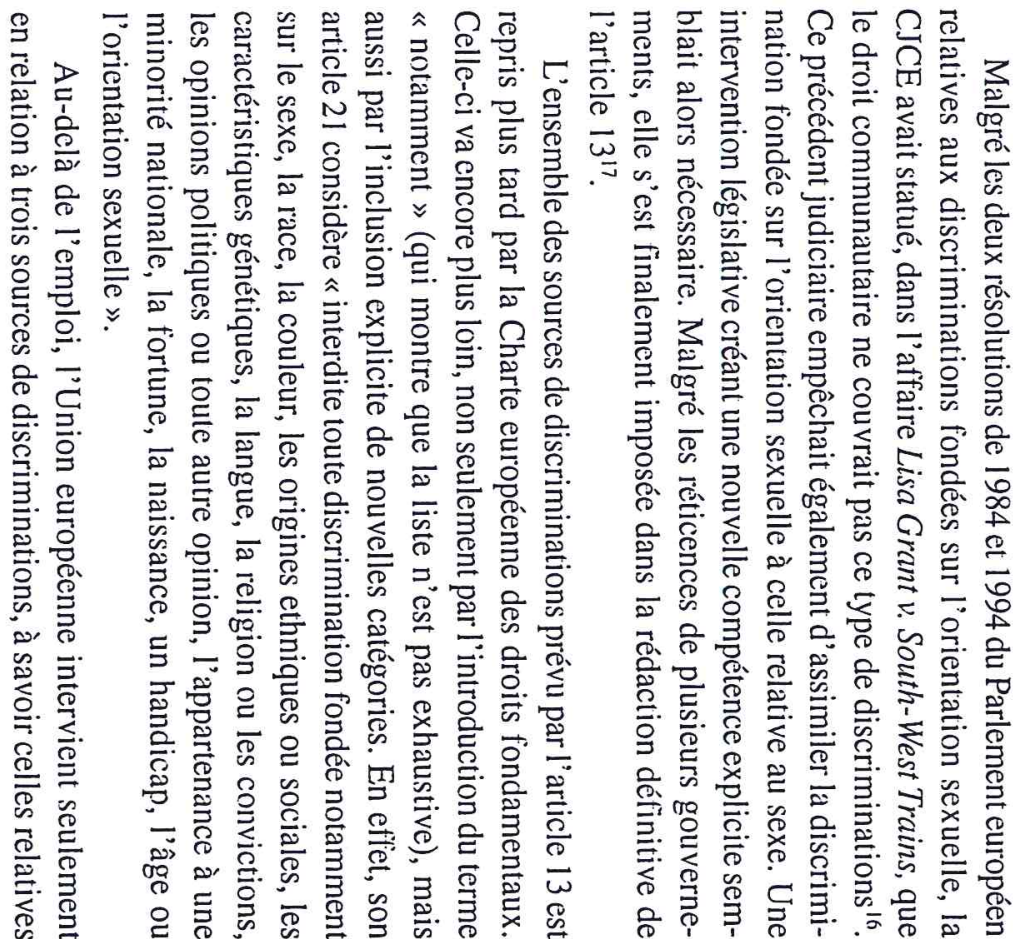

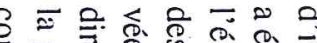

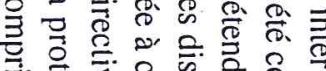

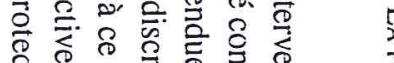

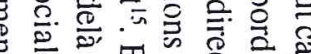
ป त অ

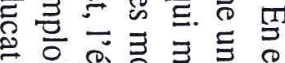

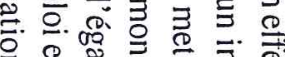

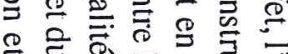

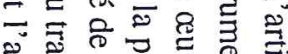

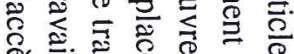

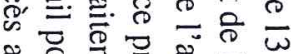

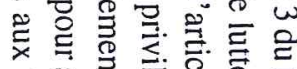

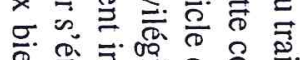

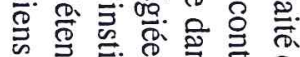

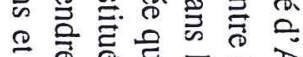

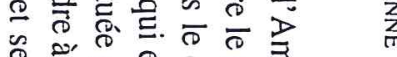

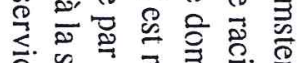

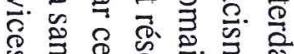
只 


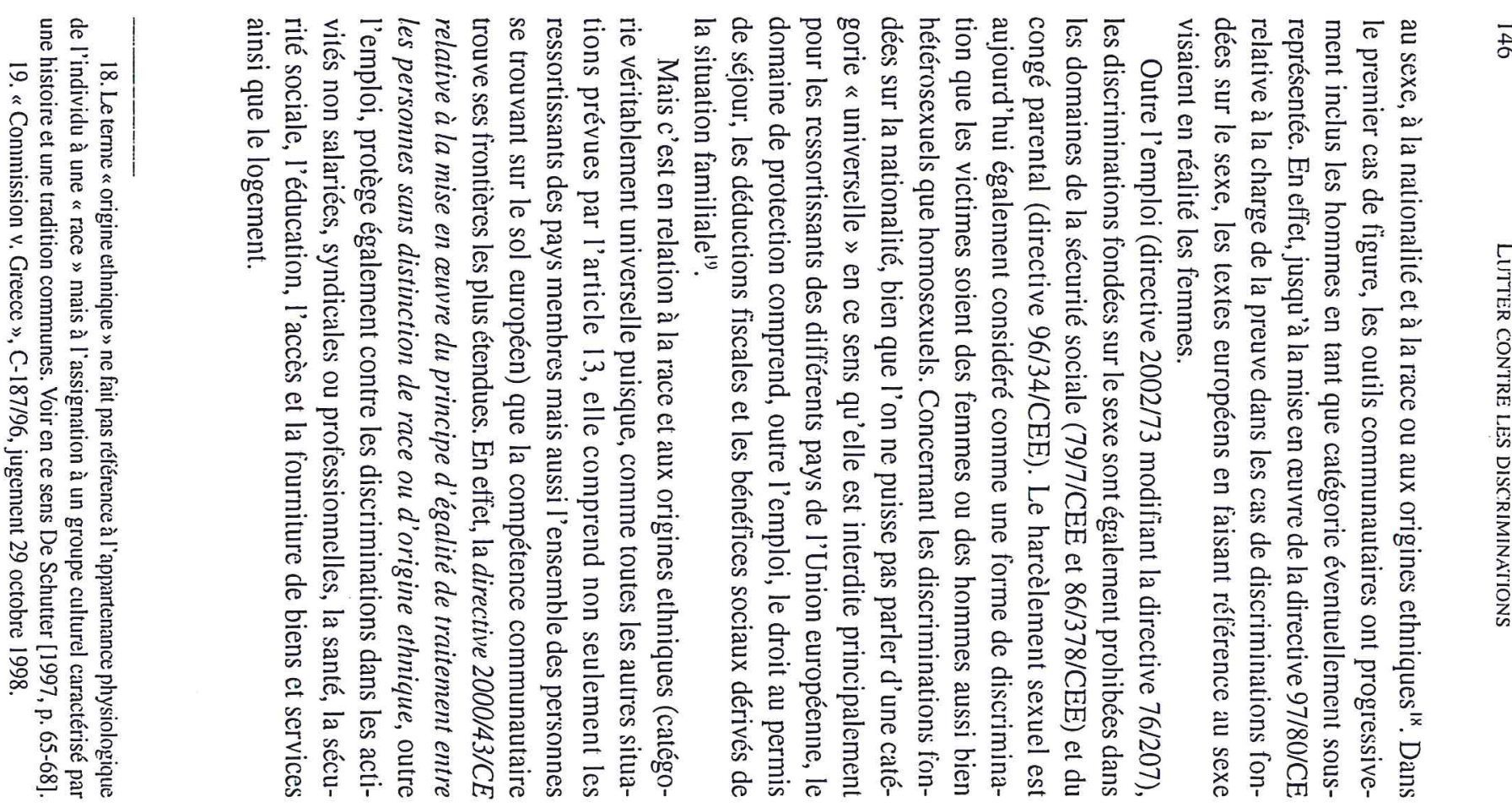

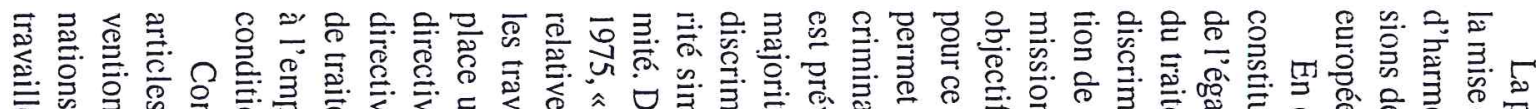

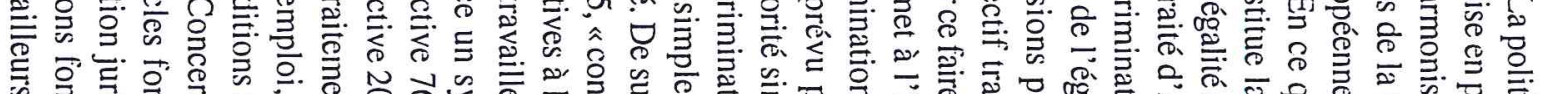

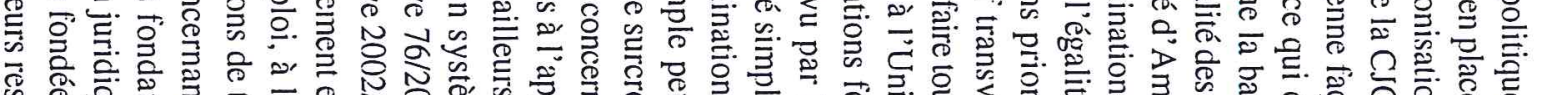

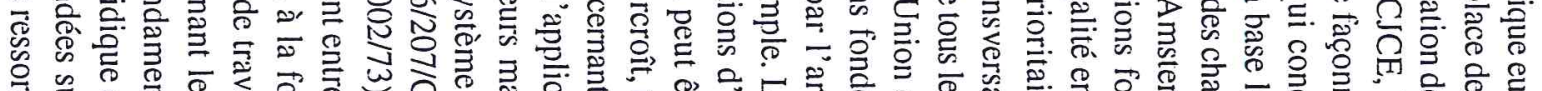

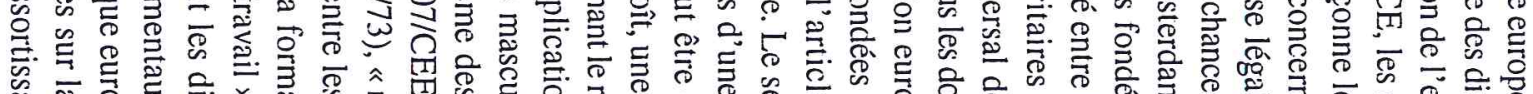

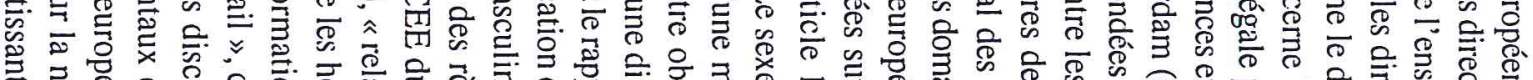

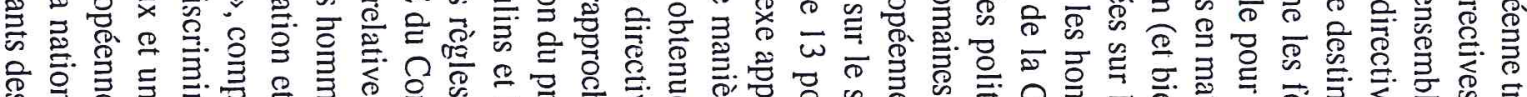

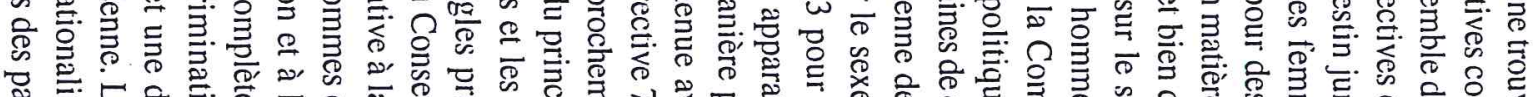
选它:

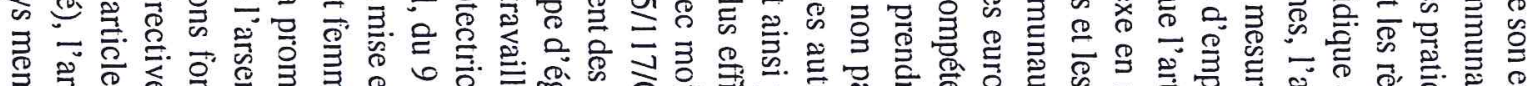

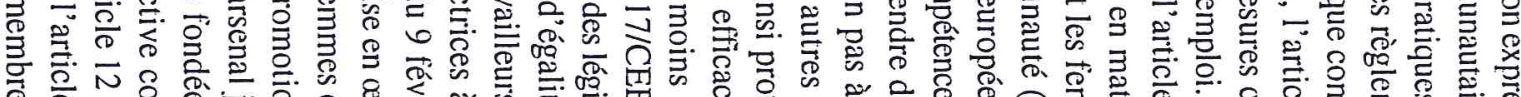

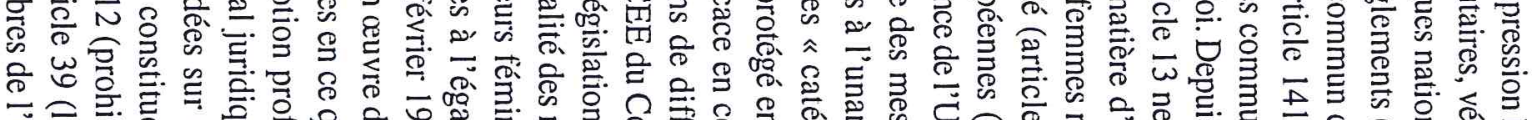

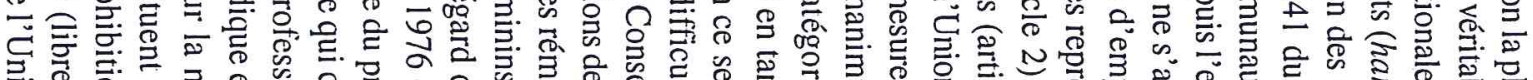

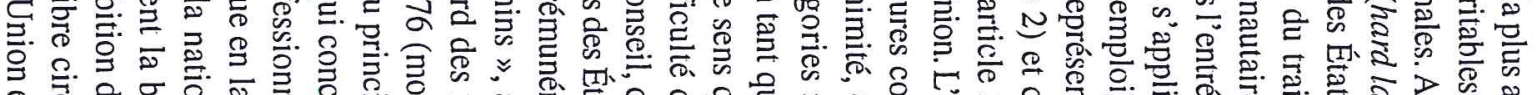

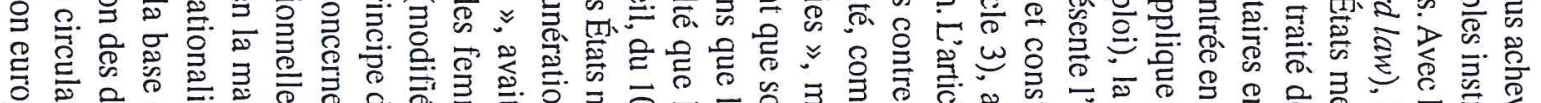

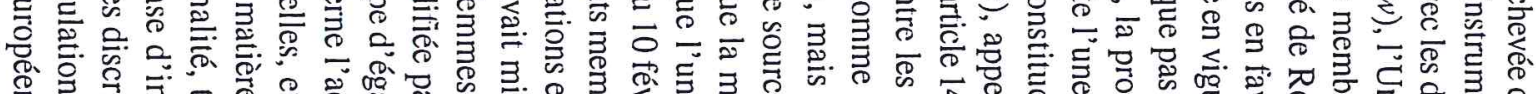

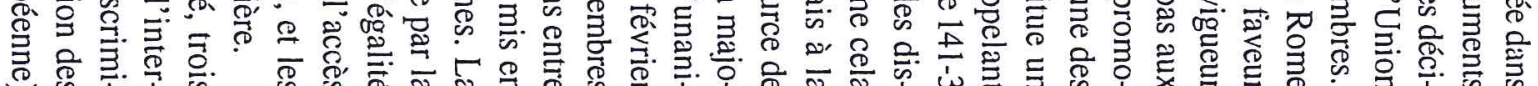




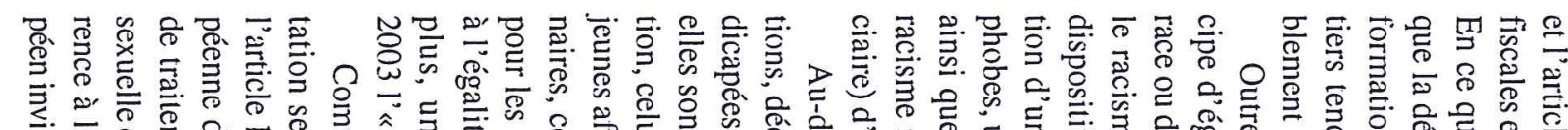

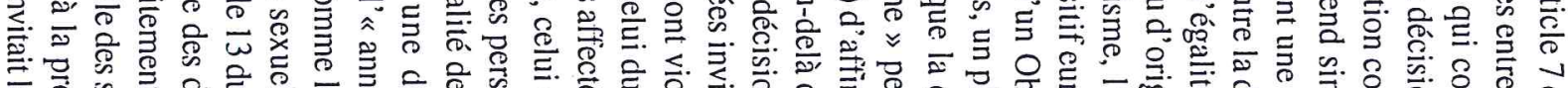

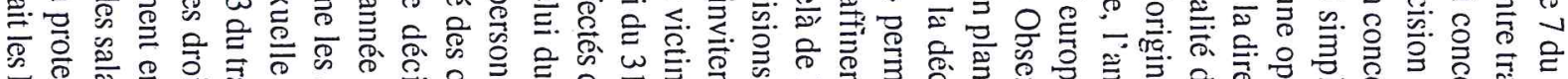

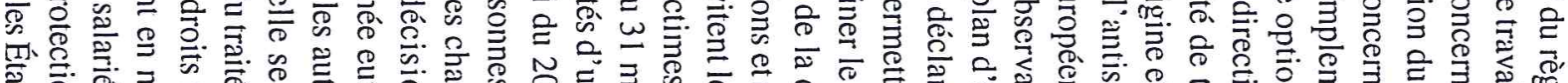

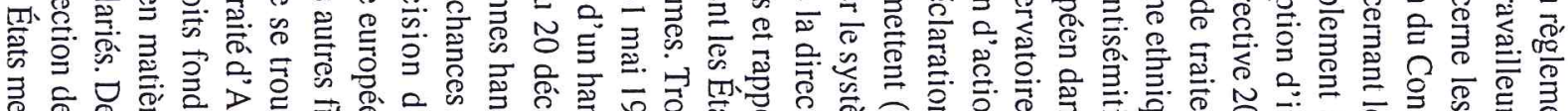

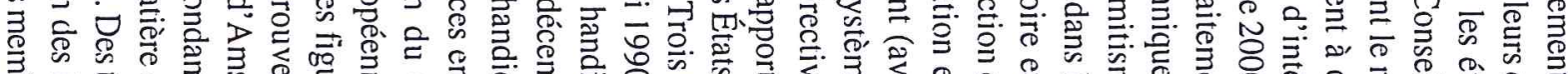

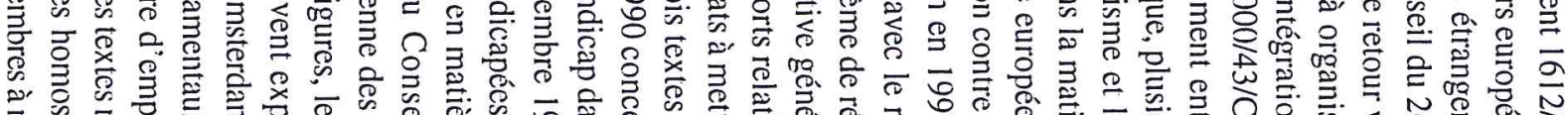

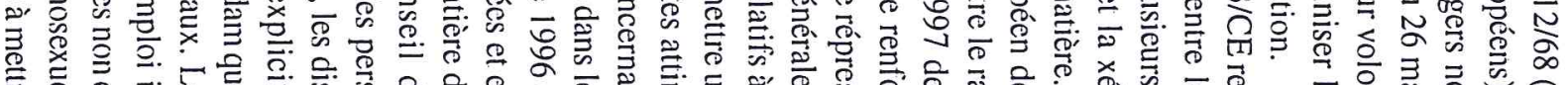

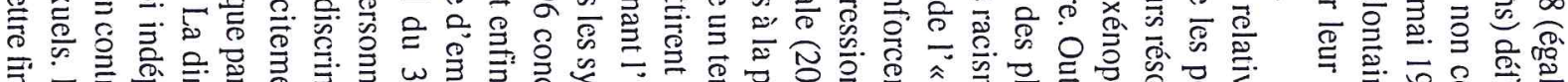

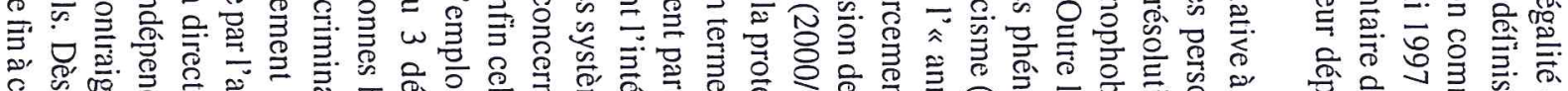

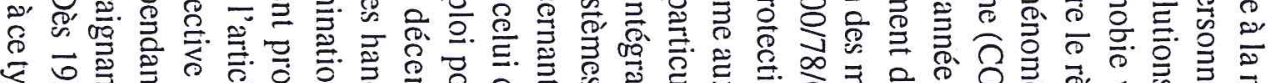

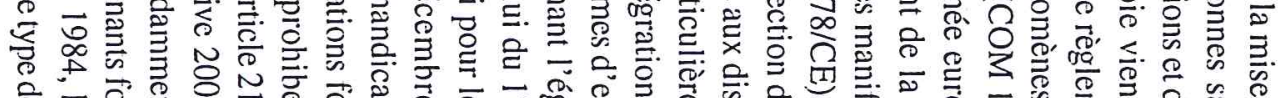

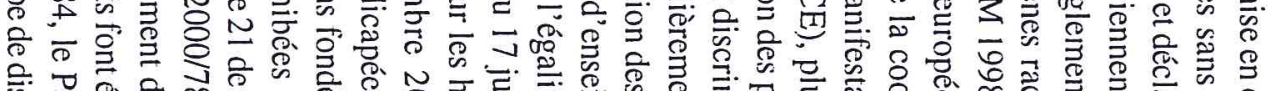

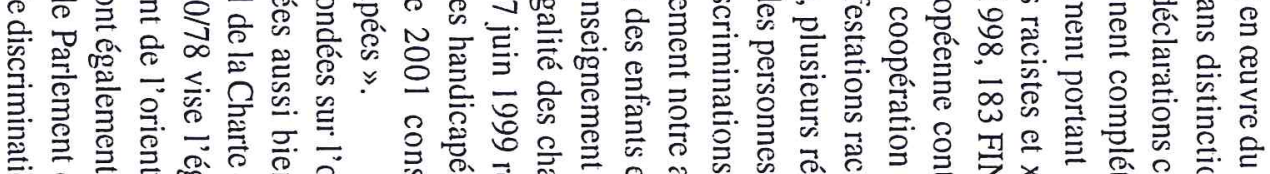

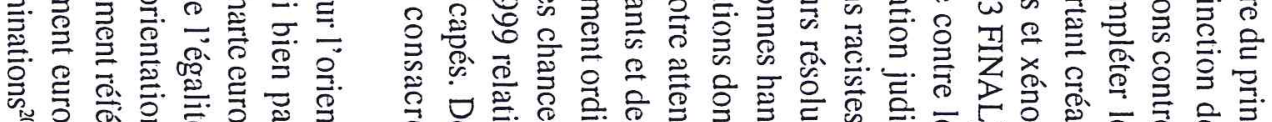

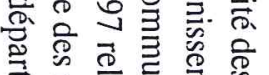

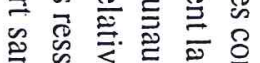

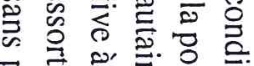

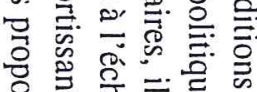

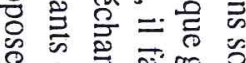

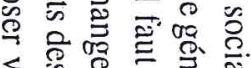

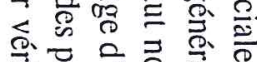

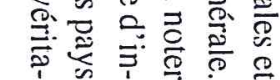

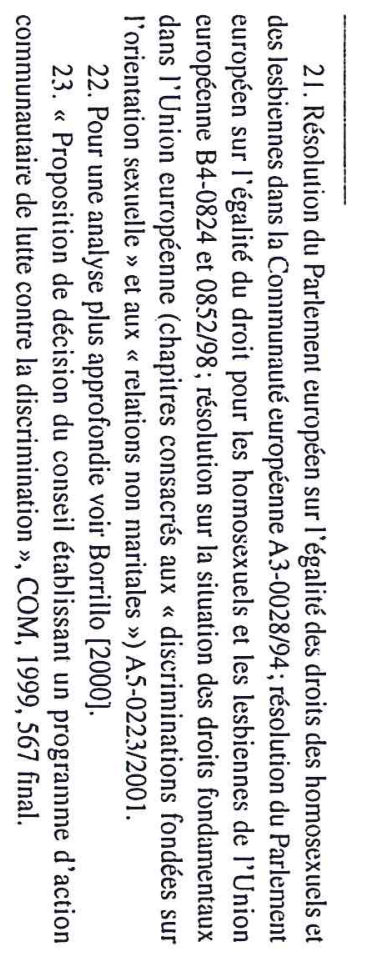

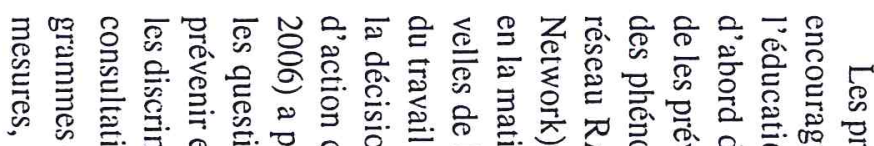

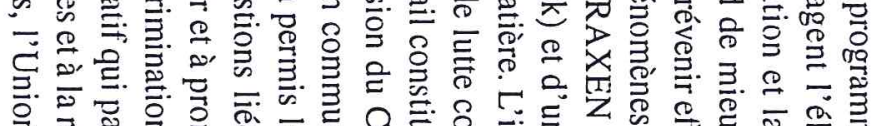

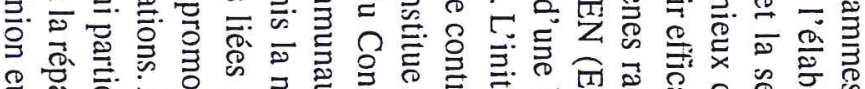

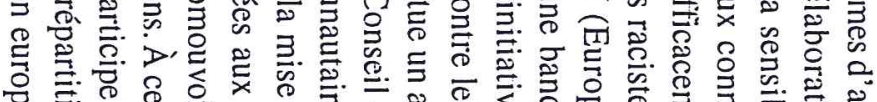

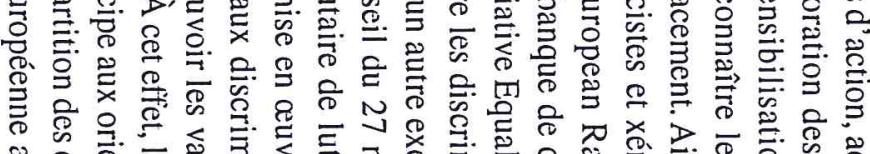

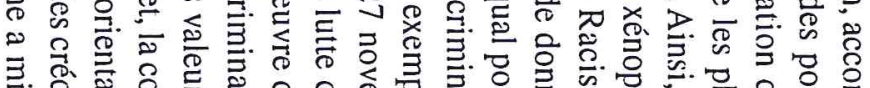

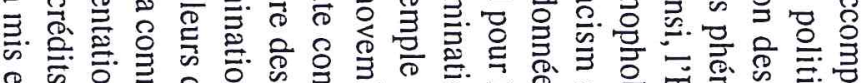

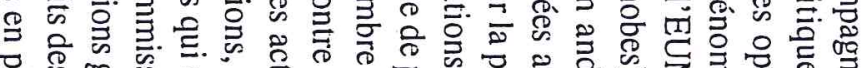

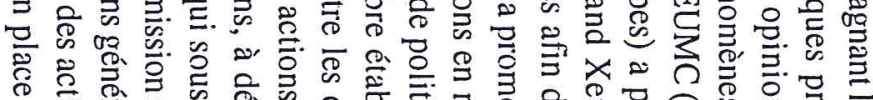

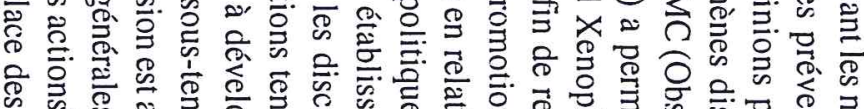

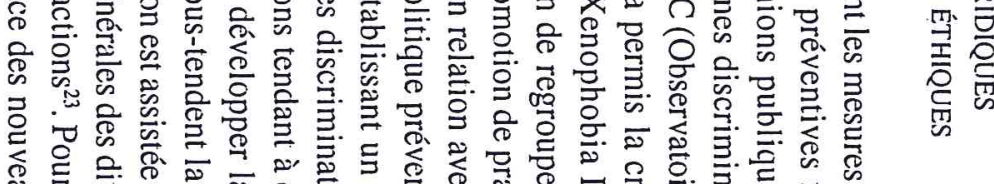

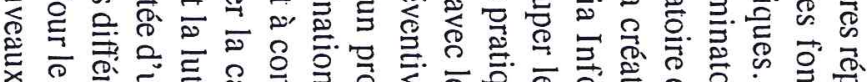

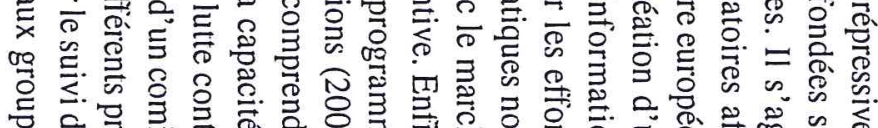

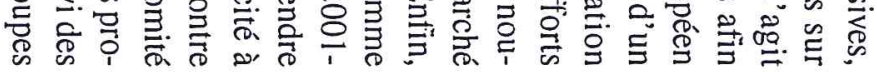

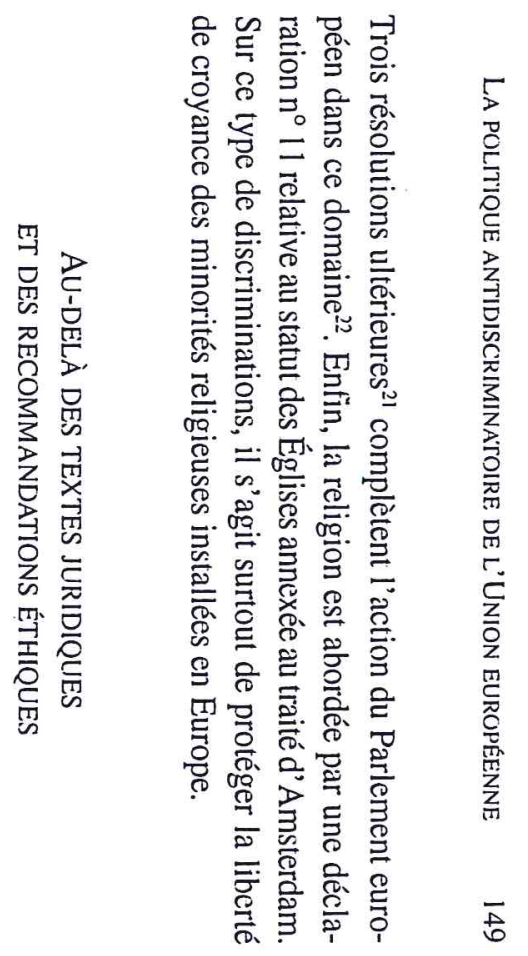




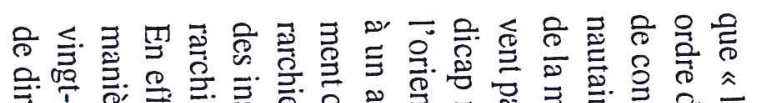

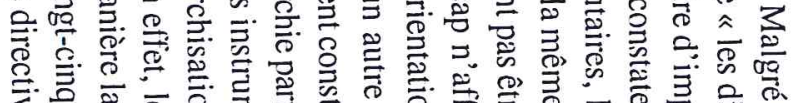

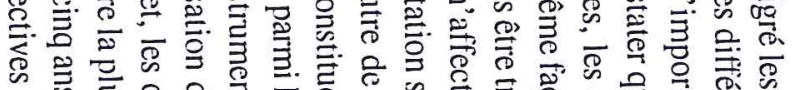

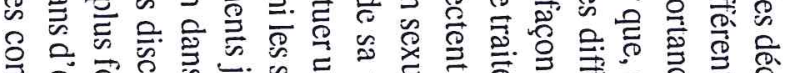

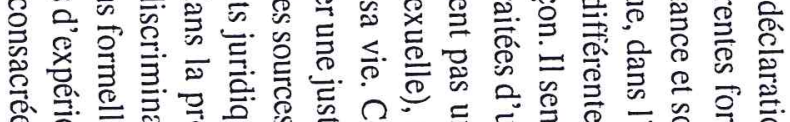

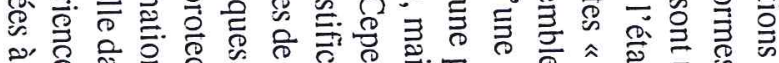

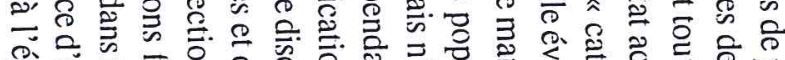

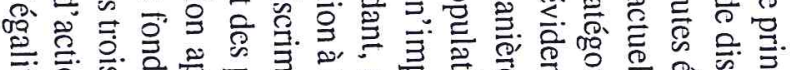

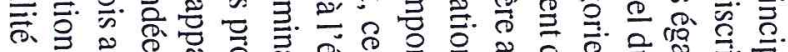

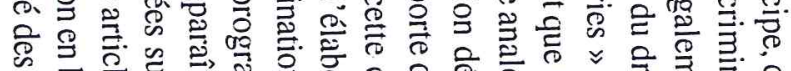

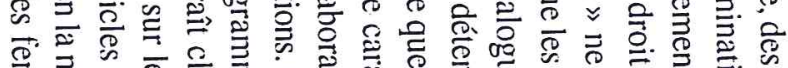

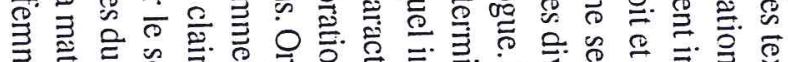

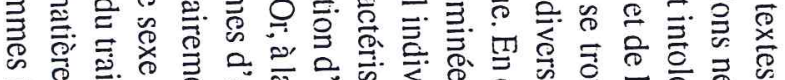

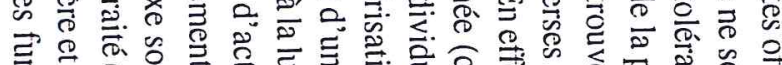

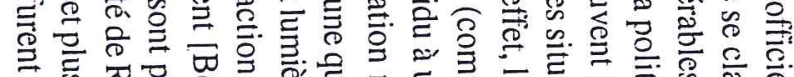

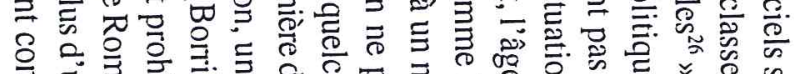

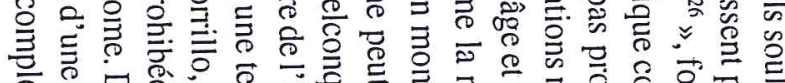

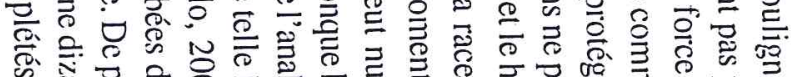

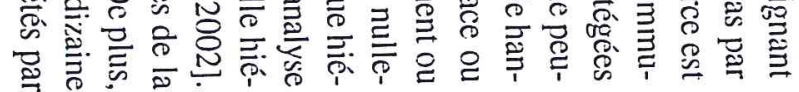

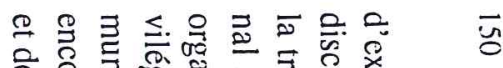

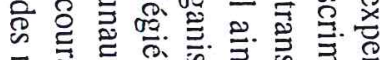

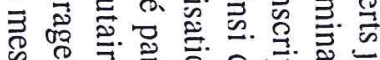

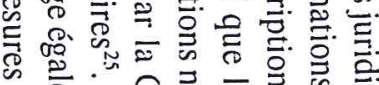

$\stackrel{\overbrace{}}{\overparen{\Xi}}$ का

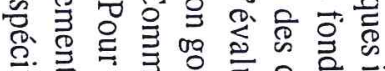

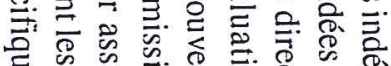

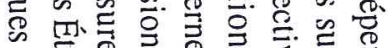

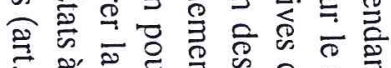

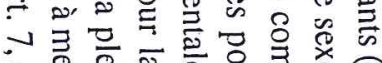

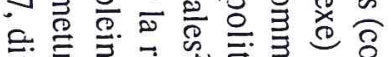

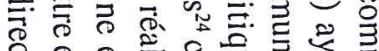

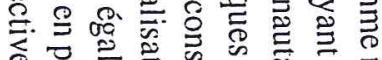

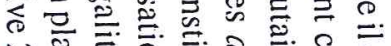

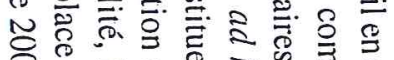

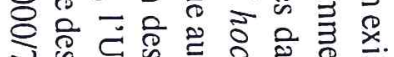

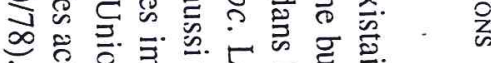

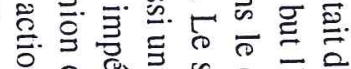

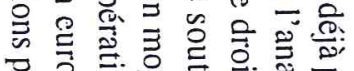

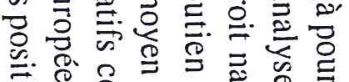

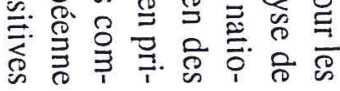

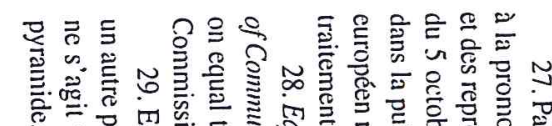

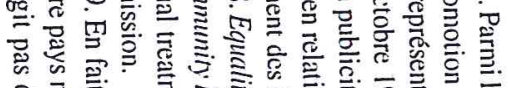

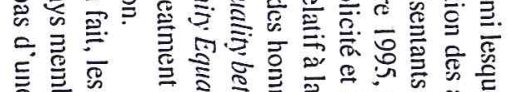

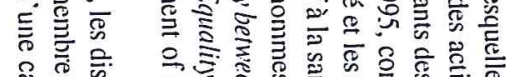

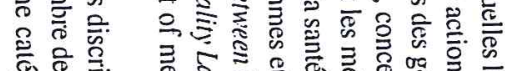
o.

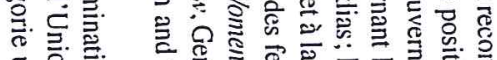

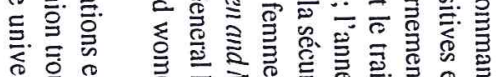

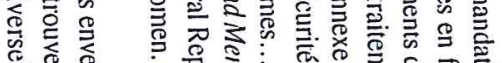

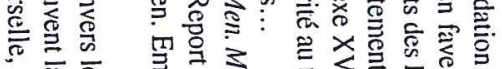

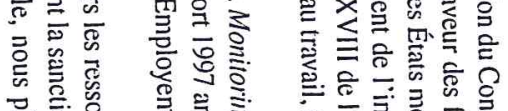

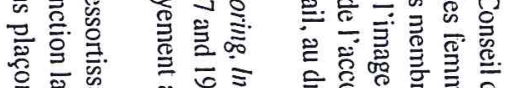

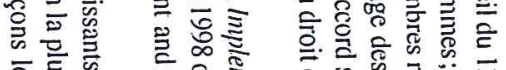

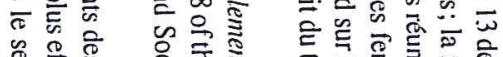

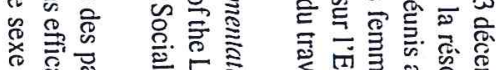

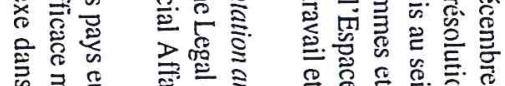

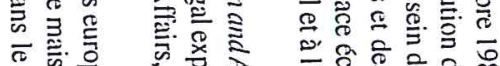

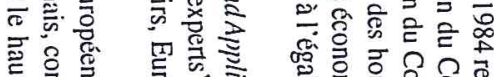

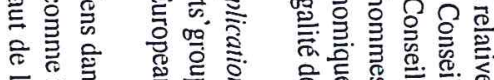

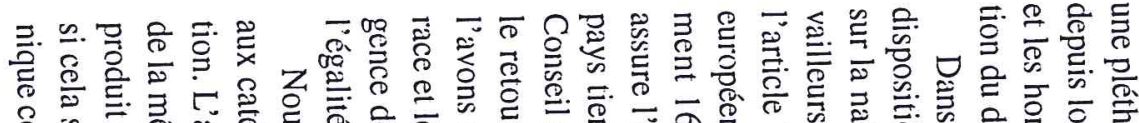

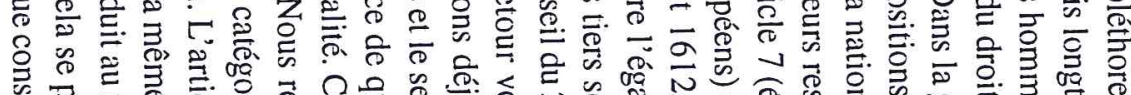
䒿

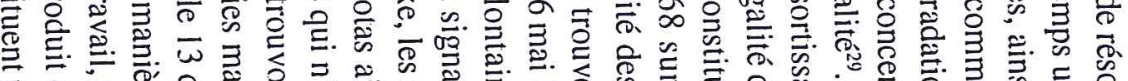

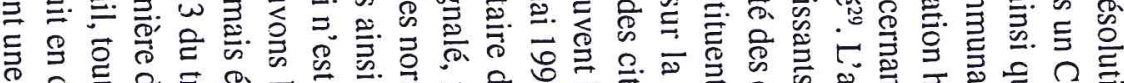

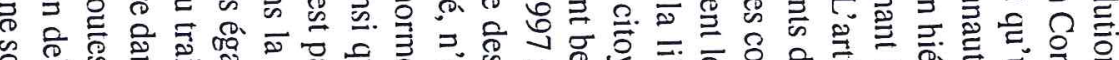

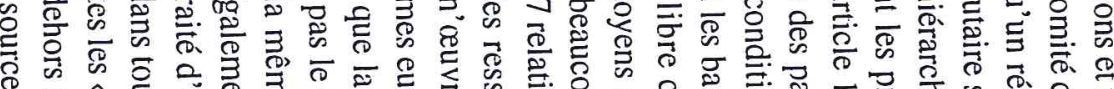

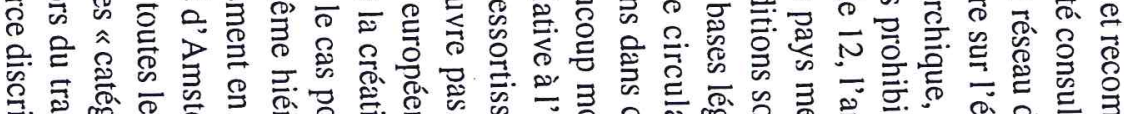

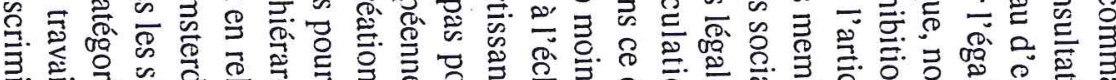

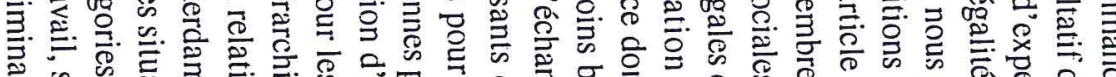

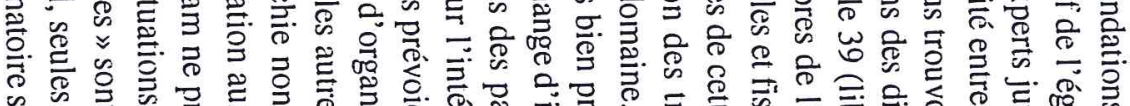

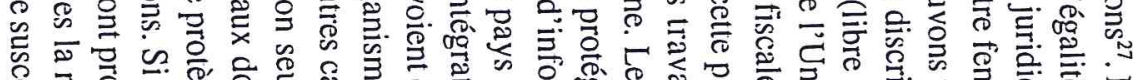

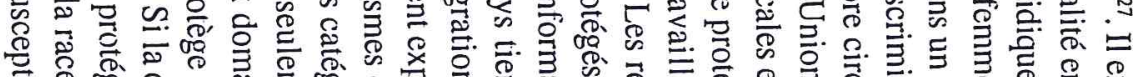

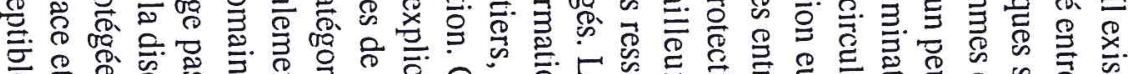

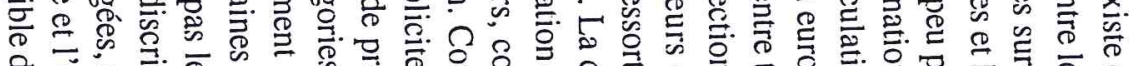

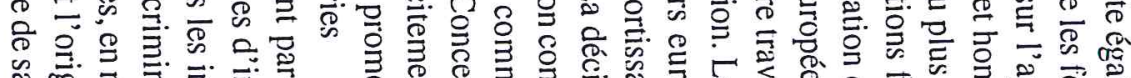

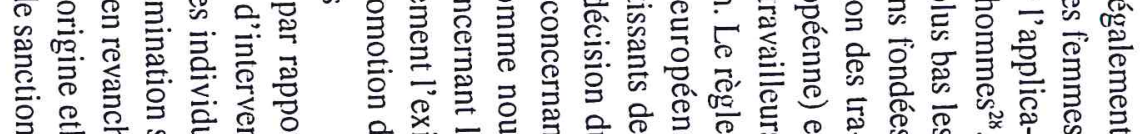



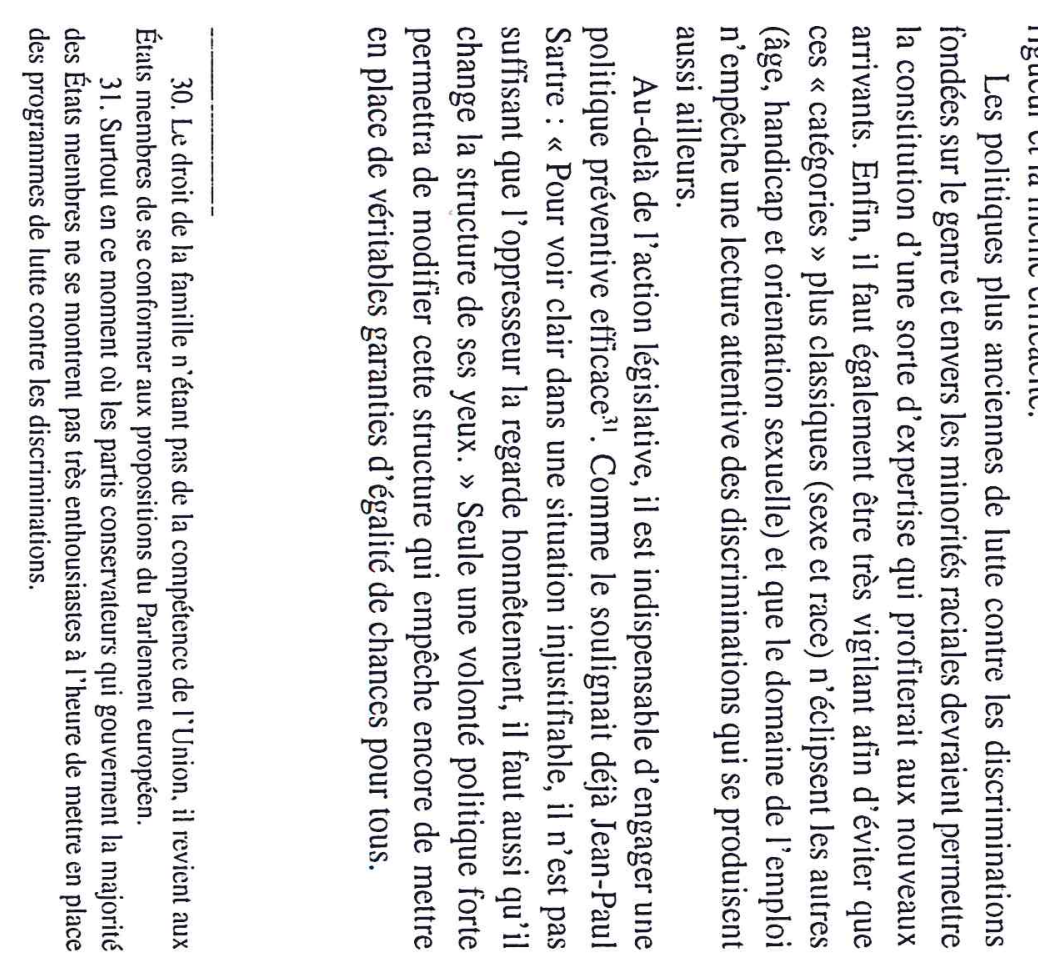

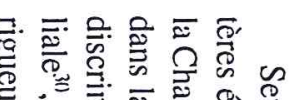

늘.

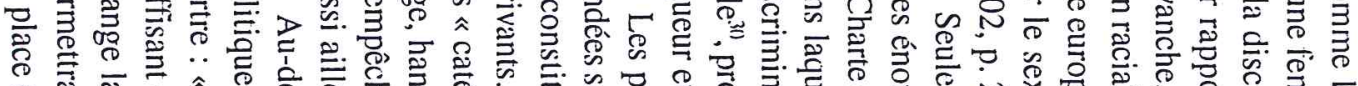

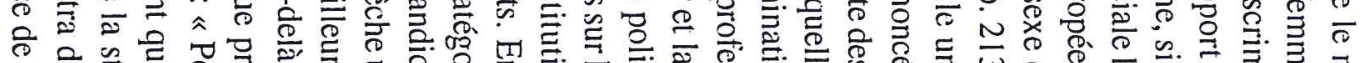

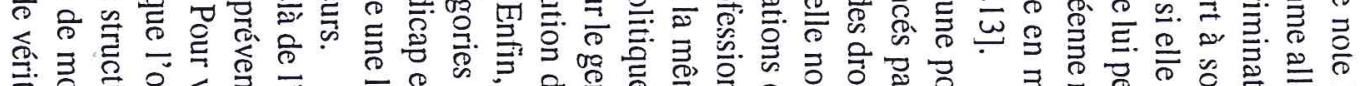

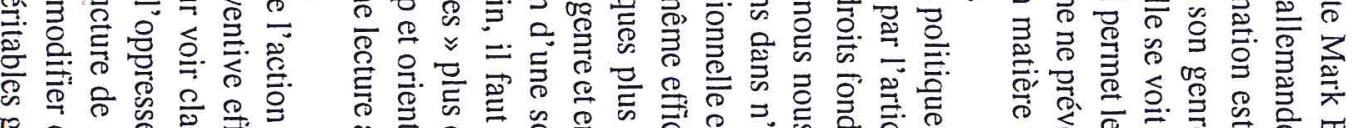

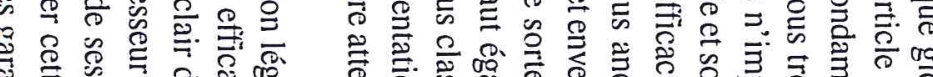

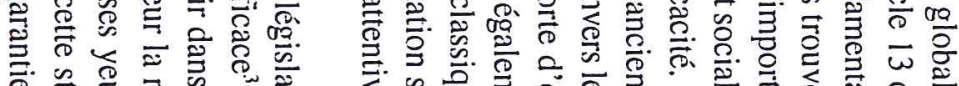

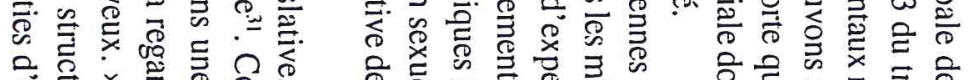
ชุ

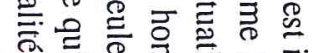
กิ

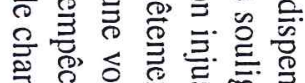
के के 引

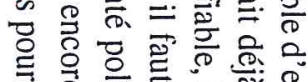

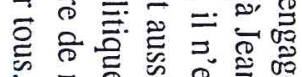

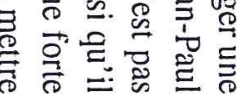

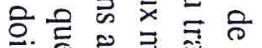

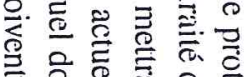

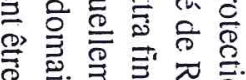

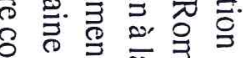

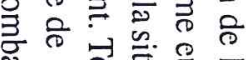
产金焉㤩

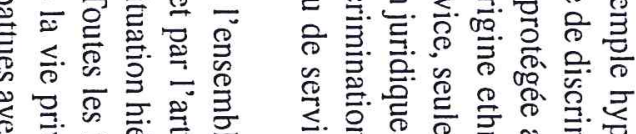

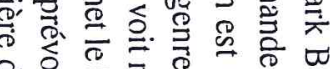

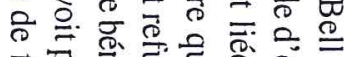

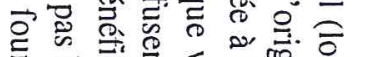

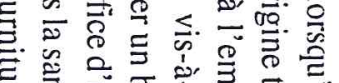

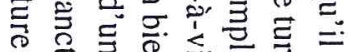
응 可市

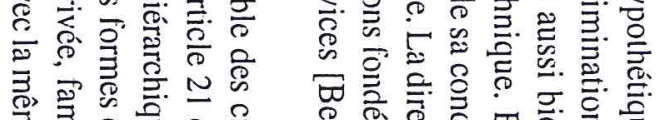

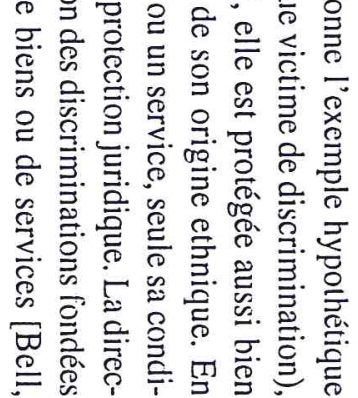

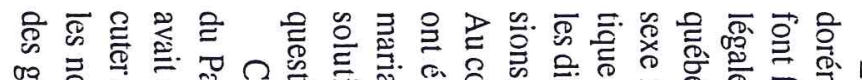

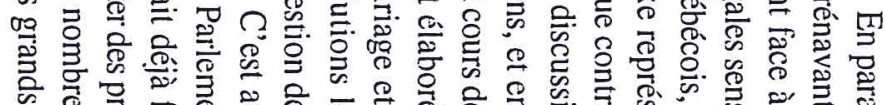

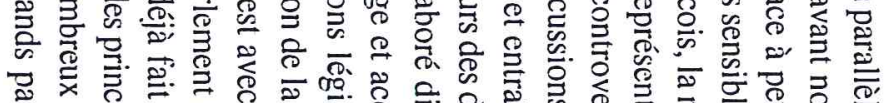

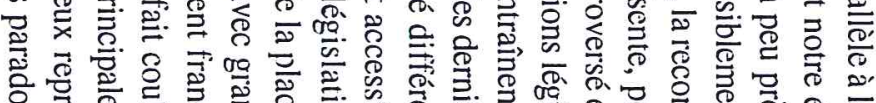

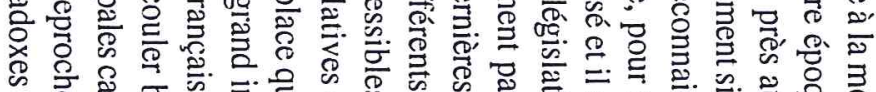
क

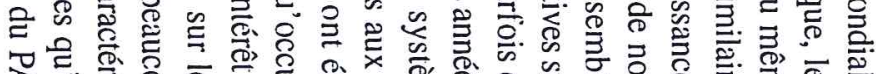

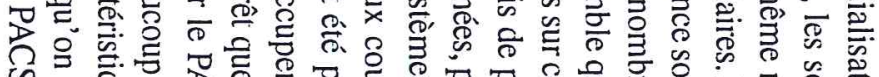

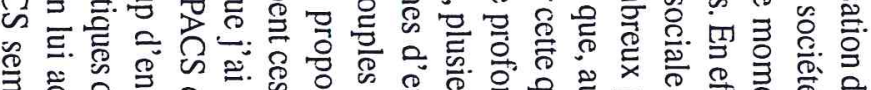

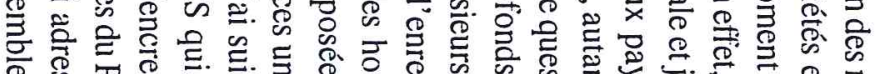

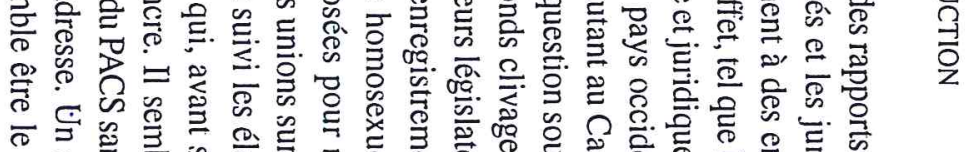

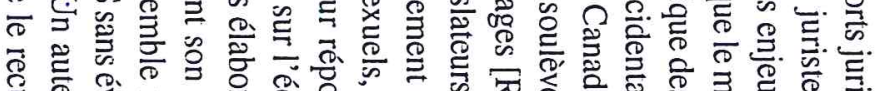

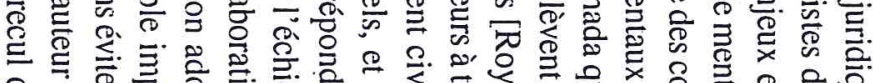
(a) $\frac{\overline{3}}{3}$

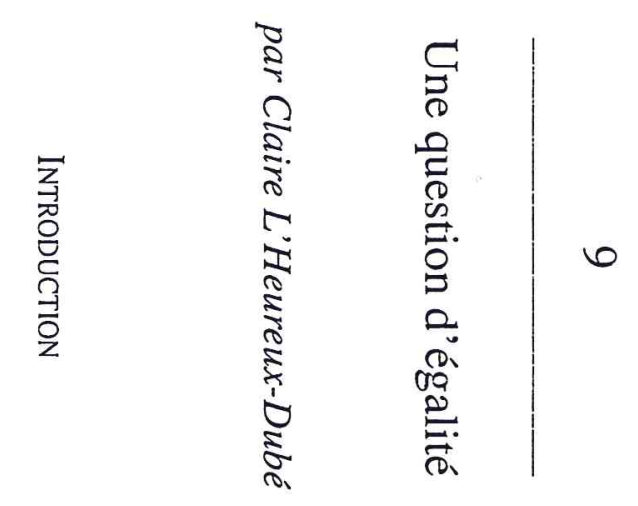

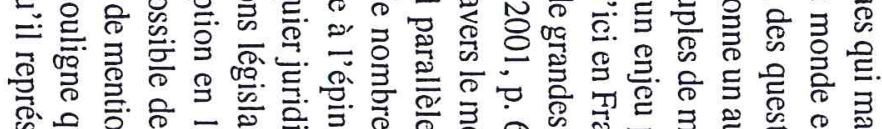

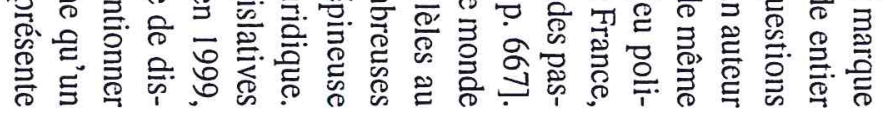

